\title{
Digestibility and digestive enzyme activity in Labeo fimbriatus (Bloch, 1795) fed periphyton grown on sugarcane bagasse
}

\author{
B. GANGADHAR, N. SRIDHAR, H. UMALATHA, H. GANESH, A. R. T. SIMON* \\ AND P. JAYASANKAR \\ ICAR-Central Institute of Freshwater Aquaculture, Regional Research Centre, Hesaraghatta Lake P.O., \\ Bangalore - 560 089, Karnataka, India \\ "Federal Institute of Education, Science and Technology, Manaus, Amazonas, Brazil \\ e-mail: gbarlaya@yahoo.co.in
}

\begin{abstract}
An experiment of 60 days duration was carried out to compare dry matter and protein digestibility of periphyton grown on sugarcane bagasse bundles and a pelleted feed in Labeo fimbriatus (Bloch, 1795). Advanced fingerlings maintained in glass aquaria were allowed to feed on fresh periphyton or pelleted feed ( $20 \%$ crude protein) daily morning, the fecal matter collected following standard procedure and analysed for proximate composition. Acid insoluble ash was used as the reference marker for digestibility estimation. Activity of total protease, trypsin, chymotrypsin, carboxypeptidase - A and B, amylase, lipase and cellulase in the gut of fish was estimated at the end of the feeding trial. Periphyton and pelleted feed showed similar ( $p>0.05$ ) protein digestibility (92.29 and $89.21 \%$ respectively), while total dry matter digestibility was higher $(\mathrm{p}<0.05)$ with peiphyton $(85.44$ and $75.16 \%$ respectively). Among the proteases estimated, activity of total protease and carboxypeptidase B was higher $(\mathrm{p}<0.05)$ in fish fed periphyton, whereas activity of others showed no difference between those receiving periphyton and pelleted feed $(\mathrm{p}>0.05)$. Activity of carbohydrases and lipase was higher in fish fed pelleted feed. Results of the study cleary indicated that $L$. fimbriatus can efficiently utilise periphyton.
\end{abstract}

Keywords: Digestibility, Digestive enzymes, Fringe-lipped carp, Labeo fimbriatus, Periphyton, Pelleted feed, Sugarcane bagasse

\section{Introduction}

Increase in production of several herbivorous fish species has been reported in periphyton-based aquaculture (Wahab et al., 1999; Azim et al., 2005; Keshavanath et al., 2001b, 2002, 2004; Gangadhar and Keshavanath, 2012). Labeo fimbriatus (Bloch, 1795) is considered as a suitable candidate for species diversification in culture. Though slow-growing, this medium sized carp is in good demand due high market value, excellent flavour and meat quality especially in peninsular India (Basavaraju et al., 1995). Published work on L. fimbriatus is limited (Mridula et al., 2003; Saravanan et al., 2011; Rao 2011; Swain et al., 2013). L. fimbriatus is basically a benthic fish which graze on algae, protozoa, rotifers and diatoms that grow on submerged rocks and twigs (Bhatnagar and Karamachandani, 1970; Talwar and Jhingran, 1991; Das, 2011). In a grow-out study, Jena et al. (2011) demonstrated the compatibility of this species in polyculture with major carps. Keshavanath et al. (2002) and Mridula et al. (2003) have reported L. fimbriatus as a good periphyton grazer.

Digestibility is the relative measure of the extent to which ingested food and its nutrient components are digested and absorbed by the animal and is considered as one of the important factors in diet evaluation. The ability of L. fimbriatus to digest periphyton and absorb nutrients has not been quantified yet. Hence, the present study was undertaken using sugarcane bagasse, which has been already reported to be a good periphyton substrate (Keshavanath et al., 2001a; Mridula et al., 2003; Gangadhara and Keshavanath, 2008) that enhances fish growth (Ramesh et al., 1999; Keshavanath et al., 2001b; Gangadhara and Keshavanath, 2012). Activity of major digestive enzymes viz., total protease, trypsin, chymotrypsin, carboxypeptidase A and B, amylase, lipase and cellulase in the gut of fish fed periphyton in comparison with fish fed pelleted feed was estimated to validate the results.

\section{Materials and methods}

Growing periphyton

Outdoor cement tanks ( $6 \times 4 \times 1.2 \mathrm{~m})$ with $5 \mathrm{~cm}$ soil base were used for growing periphyton. Sugarcane bagasse was used as the substrate for growing periphyton. Fresh bagasse procured from local sugarcane juice vending 
shops was soaked in water for 2 days to get rid of the sugar present and was then dried under sun. It was made into bundles of $20( \pm 2.75) \mathrm{cm}$ perimeter. Water from a nearby bore well was filled in the tanks to maintain a water column of $1 \mathrm{~m}$; the evaporation loss, which was very meager, was compensated fortnightly. Cattle dung was applied to each tank@ $5 \mathrm{t} \mathrm{ha}^{-1}$, followed by urea and single super phosphate (SSP) at 10 and $15 \mathrm{~kg} \mathrm{ha}^{-1}$, respectively. Sugarcane bagasse bundles were hung vertically at 2 t ha-1 (Keshavanath et al., 2001b), keeping almost uniform distance between them. Subsequent fertilisation was done at fortnightly intervals with cattle dung @ $0.5 \mathrm{tha}^{-1}$ and urea and SSP@10 and 15 kg ha ${ }^{-1}$, respectively.

\section{Digestibility trial}

Dry matter as well as protein digestibility of periphyton by the fish was estimated through a short term trial (Nandeesha et al., 1998) conducted in 60 (L) $\mathrm{x}$ $37(\mathrm{~W}) \times 55 \mathrm{~cm}(\mathrm{H})$ glass aquaria. Ten fingerlings each of L. fimbriatus (average weight $5.17 \pm 0.19 \mathrm{~g}$ ) were maintained in six aerated aquaria and acclimatised to laboratory conditions for a period of one week. Every morning at $1000 \mathrm{hrs}$, bagasse bundles harbouring periphyton were immersed in three 'test' tanks and allowed for fish to graze on. Fish in three aquaria were fed a pelleted feed having $20 \%$ crude protein (Table 1 ). Fish were allowed to feed for $6 \mathrm{~h}$. The bagasse bundles were removed and the uneaten periphyton/pelleted feed were siphoned out at the end of the feeding period. On the following day, fecal matter was collected from each tank by filtering the water with a fine meshed nylon cloth $(15 \mu \mathrm{m})$, dried, pooled and stored for proximate analysis. About $50 \%$ of water from each aquarium was replaced with freshwater every day after fecal matter collection. This feeding and fecal matter collection trial was conducted for a period of 60 days. Proximate composition of periphyton, pelleted feed and fecal matter was analysed (AOAC, 1995). Dry matter and protein digestibility were determined according to Maynard and Loosli (1972). Acid insoluble ash was used as the reference marker (Goddard and McLean, 2001; Li et al., 2008; Bob-Manuel, 2013).

\section{Analyses of digestive enzyme activity}

After completion of the experiment, all the fish were weighed and length recorded. Three fish from each tank were sacrificed for digestive enzyme activity analyses. Gut was dissected out and homogenised in ice cooled condition with distilled water $\left(4 \mathrm{ml} \mathrm{g}^{-1}\right)$ and centrifuged at $16,000 \mathrm{rpm}$ for $20 \mathrm{~min}$ at $4^{\circ} \mathrm{C}$. The supernatant (crude enzyme extract) was stored at $-20^{\circ} \mathrm{C}$ in $1.5 \mathrm{ml}$ aliquots until further use. Total soluble protein of the homogenate was measured using Folin-phenol reagent (Lowry et al., 1951).

Amylase activity was measured following 3,5-dinitro salicylic acid (DNS) method of Miller (1959). Total proteolytic activity was determined by the casein digestion method of Kunitz (1947). Trypsin and chymotrypsin activities were assayed according to the method of Erlanger et al. (1961). Carboxypeptidase activity was estimated following Appel (1974). Lipase activity was determined using p-nitro phenyl acetate (PNPA) as the substrate (Licia et al., 2006). Cellulase activity was determined as per Miller (1959).

\section{Statistical analyses}

Data on periphyton digestibility and digestive enzyme activity were compared employing one way ANOVA, followed by t-test.

\section{Results and discussion}

The values obtained for proximate parameters of periphyton were: crude protein $19.66 \%$, lipid $1.09 \%$, nitrogen-free extract (NFE) $37.74 \%$ and ash $32.63 \%$ (Table 1). Periphyton is a complex of sessile biota including algae, invertebrates, detritus and microorganisms. The nutrient quality and availability in periphyton is influenced by several factors like grazing pressure, algal and bacterial species composition, nutrient level of environment, water quality, light intensity and most significantly substrate type (Makarevich et al., 1993; Azim et al., 2002; Gangadhara and Keshavanath, 2008). Montgomery and Gerking (1980) reported proximate composition of periphyton grown on granite boulders suspended in the Gulf of California. Protein, lipid, carbohydrate and ash contents of these epilithic periphyton were 8-10, 2-5, 52-60 and 25-38\% respectively. An average protein content of $15 \%$ was estimated in periphyton collected from coral reef (Polunin, 1988). Dempster et al. (1995) reported 28-55\% protein and 5-18\% lipid in some algal species of periphytic nature. Proximate composition of periphyton from different substrates varied from 9 to $32 \%$ protein, 2-9\% lipid, 25-28\% NFE and 16-42\% ash (Thompson et al., 2002; van Dam et al., 2002; Azim et al., 2005). Our earlier findings with

Table 1. Proximate composition (\% on dry matter basis, mean \pm SD) of experimental feeds

\begin{tabular}{lllllll}
\hline Sample & Moisture & Crude protein & Fat & Crude fibre & Ash & Nitrogen-free extract (NFE) \\
\hline Pelleted feed* & $5.37 \pm 0.37$ & $20.92 \pm 0.15$ & $10.44 \pm 0.03$ & $16.81 \pm 0.11$ & $6.78 \pm 0.04$ & $39.68 \pm 0.02$ \\
Periphyton & $2.92 \pm 0.26$ & $19.66 \pm 0.25$ & $1.09 \pm 0.04$ & $5.97 \pm 0.40$ & $32.63 \pm 0.03$ & $37.73 \pm 0.32$ \\
\hline
\end{tabular}

Feed comprised groundnut cake, rice bran, finger millet flour and vitamin and mineral mixture at 40, 50, 9 and $1 \%$ respectively. 
periphyton from sugarcane bagasse revealed the following proximate composition: crude protein $26.06 \%$, lipid $3.08 \%$, NFE 38.02\% and ash 17.45\% (Gangadhara and Keshavanath, 2008), while Mridula et al. (2003) recorded $9.4,0.33,38$ and $23 \%$ values for the respective parameters.

It has been documented that nutritional composition of periphyton can be considered as broadly appropriate to fish dietary needs (Dempster et al., 1993; Makarevich et al., 1993; Azim et al., 2002). Algal proteins in periphyton are also considered to be of good quality (Oser, 1959; Van Der Meeren et al., 2007). Apart from being a source of macronutrients, microalgae and heterotrophic bacteria are a rich source of immune enhancers (Supamattaya et al., 2005), growth promoters (Kuhn et al., 2010), bioactive compounds (Ju et al., 2008) and dietary stimulants (Xu et al., 2013) which can enhance growth performance of cultured fish. The protein level of $19.66 \%$ recorded in periphyton from bagasse (Table 1) compares well with the quality of some of the natural plant feeds that have been used in aquaculture (Yakupitiage, 1993; Dempster et al., 1995). The protein requirement of freshwater fishes especially that of carps, varies between $25-35 \%$, depending upon age and culture conditions (Hossain et al., 1997; Keshavanath et al., 2002). Studies with rohu have shown that in fertilised ponds, the growth obtained with 20 and $25 \%$ protein feeds were similar ( $>0.05)$ (Nandeesha et al., 1994).

The high ash content of more than $30 \%$ in periphyton is attributed to the suspended clay particles (detritus) in the water column that are subsequently trapped on the substrates. Huchette et al. (2000) and Yakupitiyage (1993) stated that ash content lesser than $30 \%$ is reasonable in fish nutrition. However, ash per se is not harmful, but replaces nutritive components in feeds. High ash content of some plant fodders has been found not to impair the growth of tilapia (Yakupitiyage, 1993). Further, Azim et al. (2003) and Kaggwa et al. (2006) found that the high ash content (55 and $71 \%$ of dry matter, respectively) in periphyton had a positive effect on fish yields. Hence, the nutritional quality of periphyton, observed in the present study qualifies it to be considered as a dietary supplement for fish.

The dry matter digestibility values were lesser than the protein digestibility values (Fig. 1). Studies with rohu have also revealed such trends (Salim et al., 2004; Gul et al., 2007). Dry matter digestibility value recorded with L. fimbriatus for periphyton was higher $(\mathrm{p}<0.05)$ than that of the pelleted feed. Plant proteins are generally less digestible due to the presence of cellulose and other indigestible structural carbohydrates (Boyd and Goodyear, 1971). However, Allan and Rowland (1994) and Singh et al. (2003) have reported high apparent

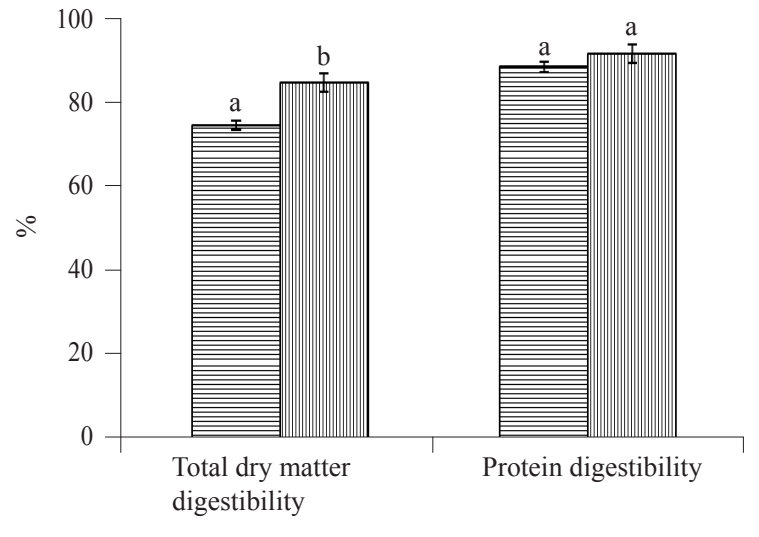

目 Pelleted feed, 皿 Periphyton

Fig. 1. Digestibility ( $\%$, mean $\pm \mathrm{SD}$ ) of periphyton in L. fimbriatus compared to pelleted feed. Different alphabets on bars for the same parameter indicate significant difference $(\mathrm{p}<0.05)$

digestibility coefficients for a number of plant products in the omnivorous carp Cirrhinus mrigala. Periphytic assemblage generally consists of chlorophytes, cyanophytes, myxophytes, diatoms, freshwater oligochaetes, protozoa, rotifers, coelenterate hydrozoa, cyanobacteria as well as free bacteria. Hence, periphyton contains substantial percentage of animal components also. Digestibility values recorded in the present study were higher compared to those obtained with other carps (mahseer, grass carp, rohu, mrigal, common carp and catla) and red tilapia, which ranged from 21 to $43 \%$ and 49 to $71 \%$ respectively, for periphyton grown on bamboo substrate (Gangadhara et al., 2004). $L$ fimbriatus is a riverine fish that is known to feed on periphyton in its natural habitat. It has fringed-lips for sucking growth on submerged objects. Being an omnivorous fish, it feeds on diatoms, Cyanophyceae, Chlorophyceae, Myxophyceae, Bacillariophyceae, plant tissue, copepods, insects and lower crustacean eggs (David and Rajgopal, 1974). Species composition of periphyton from bagasse has revealed ample availability of varied plankton (Gangadhara and Keshavanath, 2008). Further, live food is known to stimulate digestive enzyme production, contribute enzymes and also facilitate a better nutrient absorption as it contains approximately 75\% water (Holt, 1993). The microorganisms present in periphyton represent a complementary food source, providing essential nutrients, particularly amino acids, polyunsaturated fatty acid, sterols, vitamins and pigments (Thompson et al., 2002). Composition of periphyton and its impact on enzyme activity would have facilitated higher dry matter digestibility in L. fimbriatus.

Protein digestibility values for periphyton and pelleted feed were comparable $(\mathrm{p}>0.05)$. Generally, the 
protein quality of a diet is the leading factor affecting fish performance and protein digestibility is the first measure of its availability to the fish. Though it is reasonable to expect that the quality of protein from periphyton is better than that of the pelleted feed, lower protein content of the two could be the reason for the similar digestibility values recorded.

Ability of any fish to digest a given diet and absorb nutrients depends on the presence and the quality of digestive enzymes. In other words, nutrient digestibility is positively correlated with digestive enzyme activity (Hidalgo et al., 1999; De et al., 2015). Among proteases estimated in the present study, activity of total protease and carboxypeptidase B were higher $(p<0.05)$ in fish fed periphyton, while the activity of others showed no difference between fish fed with periphyton and pelleted feed (p>0.05) (Fig. 2). Further, activity of carbohydrases and lipase were higher in fish fed pelleted feed. Digestive enzyme activity is known to be affected by proximate composition of the feed (Hofer, 1979; Fountoulaki et al., 2005). It may be noted that the periphyton was fed on wet basis and hence the nutrient content on wet weight basis will be lesser than pelleted feed which was fed dry.

Mridula et al. $(2003,2005)$ reported higher digestive enzyme activity in L. fimbriatus and L. rohita grown in feed + periphyton treatment, compared to fish fed pelleted feed. High digestive enzyme activity coupled with high growth has been observed in Etroplus suratensis grown in ponds provided with substrate, followed by those receiving feed and the control (Kumar et al., 2009). An

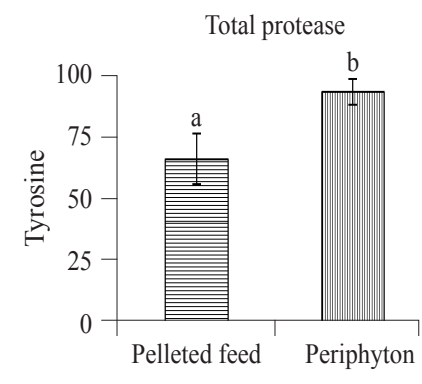

(a)

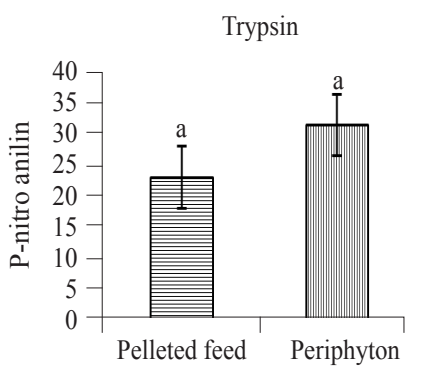

(e)

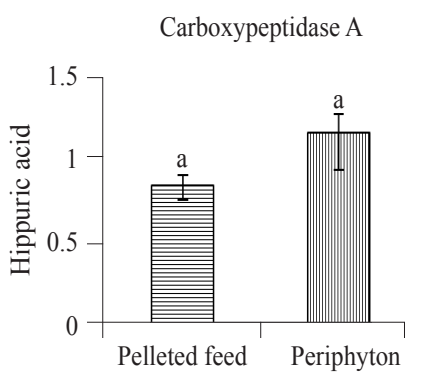

(b)

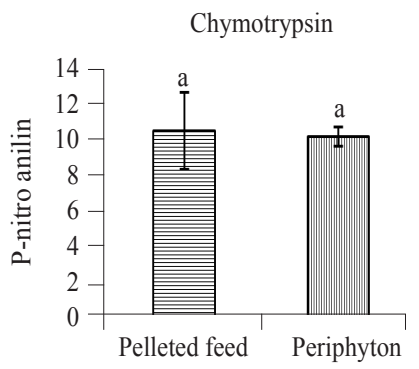

(f)

overall enhancement in protease and amylase activities was observed in shrimp fed biofloc (Xu et al., 2013). Presence of microalgae and its components/live food even at low concentration in the gut can trigger the production of digestive enzymes in fish (Kamarudin et al., 1999; Brito et al., 2004). It has been noticed that microalgae enhance trypsin activity (Le Vay et al., 1993) as they contain large amounts of free amino acids (Admiral et al., 1986). Natural food not only enhances the production of digestive enzymes, but also contributes proteolytic enzymes for the digestion process in fish (Dabrowski and Glogowski, 1977). Munilla-Moran et al. (1990) reported that live food contributes significantly (43 to $60 \%$ protease, 78 to $88 \%$ esterase and 89 to $94 \%$ amylase) to the digestive process in Scopthalmus maximus larvae. Our studies revealed that periphton contains significant amount of digestive enzymes (Gangadher et al., 2016). Therefore, contribution of digestive enzymes by periphyton to L. fimbriatus digestive process cannot be ruled out. Further, small, but measurable quantity of cellulase was recorded in the gut of L. fimbriatus (Fig. 2), indicating its endogenous secretion; which is supported by the observations of Jayaram (2013).

Herbivorous fish try to compensate the lower amount of available proteins in their diet by increasing consumption rate and enzyme production (Hofer, 1982). Sabapathy and Teo (1995) also reported similar findings in rabbitfish (Siganus canaliculatus). However, this phenomenon could not be ascertained in the present study since feed containing higher protein level was not used.

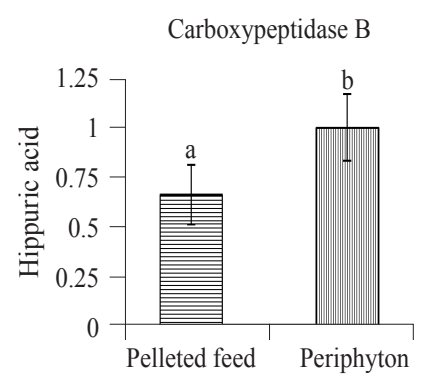

(c)

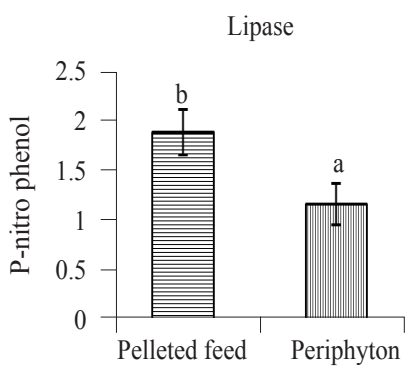

(g)

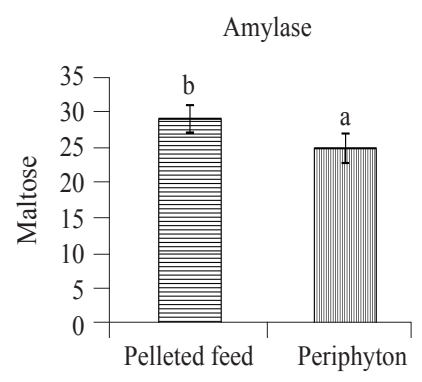

(d)

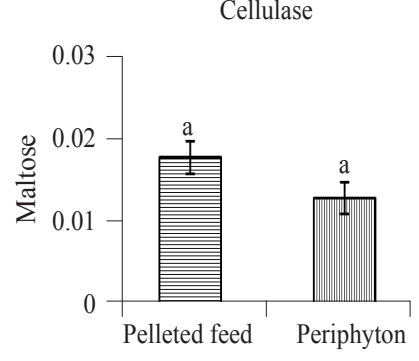

(h)

Fig. 2. Activity of digestive enzymes (mean $\pm \mathrm{SD} ; \mu$ moles of product liberated $\mathrm{h}^{-1} \mathrm{mg}$ tissue protein ${ }^{-1}$ at $25^{\circ} \mathrm{C}$ ) in the gut of $L$. fimbriatus . Different alphabets on bars in the same graph indicate significant difference $(\mathrm{p}<0.05)$ 
The results of this study demonstrated that L. fimbriatus can utilise periphyton efficiently, which has implications on the economics of its culture.

\section{Acknowledgements}

The authors are grateful to the Department of Biotechnology, New Delhi for the funding support which enabled this study under the project No. BT/PR5388/ AAQ/3/594/2012 and the Director, ICAR-Central Institute of Freshwater Aquaculture, Bhubaneswar for the infrastructure facilities provided.

\section{References}

Admiral, W., Peletier, H. and Laane, R. W. P. M. 1986. Nitrogen metabolism of marine planktonic diatoms; excretion, assimilation and cellular pools of free amino acids in seven species with different cell size. J. Exp. Mar. Biol. Ecol., 98: 241-263.

Allan, G. L. and Rowland, S. J. 1994. The use of Australian oilseeds and grain legumes in aquaculture diets. In: Chou, L. M., Munro, A. D., Lam, T. J., Chen, T. W., Cheong, L. K. K., Ding, J. K., Hooi, K. K., Khoo, H. W., Phang, V. P. E., Shim, K. F. and Tan, C. H. (Eds.), Proceedings of the third Asian Fisheries Forum. Asian Fisheries Society, Manila, Philippines, p. 667-670.

AOAC 1995. Official methods of analysis, $16^{\text {th }}$ edn. Association of Official Analytical Chemists, Washington DC, USA.

Appel, W. 1974. Peptidases. In: Bergmeyer, H. U. (Ed.), Methods of enzymatic analysis, vol. 2. Academic Press, New York, p. 949-954.

Azim, M. E., Verdegem, M. C. J., Khatun, H., Wahab, M. A., van Dam, A. A. and Beveridge, M. C. M. 2002. A comparison of fertilisation, feeding and three periphyton substrates for increasing fish production in freshwater pond aquaculture in Bangladesh. Aquaculture, 212: 227-243.

Azim, M. E., Verdegem, M. C. J., Mantingh, I., van Dam, A. A. and Beveridge, M. C. J. 2003. Ingestion and utilisation of periphyton grown on artificial substrates by Nile tilapia, Oreochromis niloticus L. Aquac. Res., 34: 85-92.

Azim, M. E., Beveridge, M. C. M., van Dam, A. A, and Verdegem, M. C. J. 2005. Periphyton and aquatic production: an introduction. In: Azim, M. E., Verdegem, M. C. J., van Dam, A. A., Beveridge, M. C. M. (Eds.), Periphytonecology, exploitation and management, CABI Publishing, Wallingford, p. 1-13.

Basavaraju, Y., Devaraj, K. V. and Ayyar, S. P. 1995. Comparative growth of reciprocal carp hybrids between Catla catla and Labeo fimbriatus. Aquaculture, 129: 187-191.

Bhatnagar, G. K. and Karamchandani, S. J. 1970. Food and feeding habits of Labeo fimbriatus (Bloch) in river Narmada near Hoshangabad (M. P.). J. Inland Fish. Soc. India, 2: 30-50.
Bob-Manuel, F. G. 2013. Methods used in digestibility evaluation of fish diets: a review and challenges. Cont. J. Fish. Aquat. Sci., 7(2): 25-37.

Boyd, C. E. and Goodyear, C. P. 1971. The nutritive quality of food in ecological systems. Arch. Hydrobiol., 69: 256-270.

Brito, R., Chimal, M. E., Gelabert, R., Gaxiola, G. and Rosas, C. 2004. Effect of artificial and natural diets on energy allocation in Litopenaeus setiferus (Linnaeus, 1767) and Litopenaeus vannamei (Boone, 1931) early post-larvae. Aquaculture, 237: 517-531.

Das, P. 2011. Diversification of freshwater aquaculture speciespotential of endemic fishes, Fishing Chimes, 31:21-22.

Dabrowski, K. and Glogowski, J. 1977. Studies on the role of exogenous proteolytic enzymes in digestion processes in fish. Hydrobiologia, 54(2): 129-134.

David, A. and Rajgopal, K. V. 1974. Food and feeding relationships of some commercial fishes of the Tungabhadra Reservoir. Proc. Indian Nat. Acad. Sci., 41: 61-74.

De, D., Ghoshal, T. K., Ananda Raja, R. and Kumar, S. 2015. Growth performance, nutrient digestibility and digestive enzyme activity in Asian seabass, Lates calcarifer juveniles fed diets supplemented with cellulolytic and amylolytic gut bacteria isolated from brackishwater fish. Aquac. Res., 46: 1688-1698. doi: 10.1111/are.12325.

Dempster, P. W., Beveridge, M. C. M. and Baird, D. J. 1993. Herbivory in the tilapia Oreochromis niloticus: a comparison of feeding rates on phytoplankton and periphyton. J. Fish. Biol., 43: 385-392.

Dempster, P. W., Baird, D. J. and Beveridge, M. C. M. 1995. Can fish survive by filter-feeding on microparticles? Energy balance in tilapia grazing on algal suspensions. J. Fish. Biol., 47: 7-17.

Erlanger, B. F., Kokowsky, M. and Cohen, W. 1961. The preparation and properties of two new chromogenic substrates for trypsin. Arch. Biochem. Biophy., 95: 271-278.

Fountoulaki, E., Alexis, M. N., Nengas, I. and Venou, B. 2005. Effect of diet composition on nutrient digestibility and digestive enzyme levels of gilthead sea bream (Sparus aurata L.). Aquac. Res., 36(13): 1243-1251.

Gangadhara, B., Keshavanath, P. and Ramesha, T. J. 2004 Digestibility of bamboo grown periphyton by carps and tilapia. J. Appl. Aquac., 15(3/4): 151-162.

Gangadhara, B. and Keshavanath, P. 2008. Planktonic and biochemical composition of periphyton grown on some biodegradable and non-degradable substrates. J. Appl. Aquac., 20: 213-232.

Gangadhara, B. and Keshavanath, P. 2012. Growth performance of rohu, Labeo rohita (Ham.) in tanks provided with different levels of sugarcane bagasse as periphyton substrate. Indian $J$. Fish., 59(3): 77-82.

Gangadhar, B., Sridhar, N., Umalatha, H., Hegde, G. and Jayasankar, P. 2016. Taxonomic and biochemical composition 
and digestive enzyme activity of periphyton and plankton: a comparative study Proc Nat. Acad. Sci. India, Sect. B. Biol. Sci., DOI: 10. 1007/s 40011-016-0805-0.

Goddard, J. S. and McLean 2001. Acid-insoluble ash as an inert reference material for digestibility studies in tilapia (Oreochromis niloticus). Aquaculture, 194: 93-98.

Gul, Y., Salim, M. and Rabbani, B. 2007. Evaluation of apparent digestibility coefficients of different protein levels with and without fishmeal for Labeo rohita. Pakistan Vet. J., 27(3): 21-125.

Hidalgo, M. C., Urea, E. and Sanz, A. 1999. Comparative study of digestive enzymes in fish with different nutritional habits: proteolytic and amylase activities. Aquaculture, 170: 267-283.

Hofer, R. 1979. The adaptation of digestive enzymes to temperature, season and diet in roach, Rutilus rutilus L. and rudd, Scardinus erythrophthalmus; protease. J. Fish. Biol., 15: 373-379.

Hofer, R. 1982. Protein digestion and proteolytic activity in the digestive tract of an omnivorous cyprinid. Comp. Biochem. Physiol., 72A: 55-63.

Holt, G. J. 1993. Feeding larval red drum on microparticulate diets in closed recirculating water system. J. World Aquac. Soc., 42: $225-240$

Hossain, M. A., Nahar, N. and Kamal, M. 1997. Nutrient digestibility coefficients of some plant and animal proteins for rohu (Labeo rohita). Aquaculture, 151(1): 37-45.

Huchette, S. M. H., Baird, D. J. and Ireland, M. 2000. The impacts of grazing by tilapias, Oreochromis niloticus L., on periphyton communities growing on artificial substrates in cages. Aquaculture, 186: 45-60.

Jayaram, K. 2013. Evaluation of digestive enzymes and kinetics of nutrient bioconversion in the peninsular carp, Labeo fimbriatus (Bloch). Ph. D. Thesis, Kuvempu University, India.

Jena, J. K., Das, P. C., Mitra, G., Patro, B., Mohanta, D. and Mishra, B. 2011. Evaluation of growth performance of Labeo fimbriatus (Bloch), Labeo gonius (Hamilton) and Puntius gonionotus (Bleeker) in polyculture with Labeo rohita (Hamilton) during fingerlings rearing at varied densities. Aquaculture, 319: 493-496.

Ju, Z. Y., Forster, I. P., Conquest, L. and Dominy, W. 2008. Enhanced growth effects on shrimp (Litopenaeus vannamei) from inclusion of whole shrimp floc or floc fractions to a formulated diet. Aquac. Nutr., 14: 533-543.

Kaggwa, R. C., Kasule, D., Van Dam, A. A. and Kansiime, F. 2006. An initial assessment of the use of wetland plants as substrates for periphyton production in seasonal wetland fishponds in Uganda. Int. J. Ecol. Env. Sci., 32(1): 63-74.

Kamarudin, M. S., Mat Isa, N. A., Sira, S. S. and Saad, C. R. 1999. Effects of diets on the survival, growth and digestive enzyme activities of Puntius gonionotus larvae. Sci. Int., 11: 91-94.

Keshavanath, P., Gangadhar, B., Ramesh, T. J., van Rooij, J. M., Beveridge, M. C. M., Baird, D. J., Verdegem, M. C. J. and van Dam, A. A. 2001a. Use of artificial substrates to enhance production of freshwater herbivorous fish in pond culture. Aquac. Res., 32: 189-197.

Keshavanath, P., Ramesh, T. J., Gangadhar, B., Beveridge, M. C. M, van Dam, A. A. and Verdegem, M. C. J. 2001b. On farm evaluation of Indian major carp production with sugarcane bagasse as substrate for periphyton. Asian Fish Sci., 14: 367-376.

Keshavanath, P., Gangadhar, B., Ramesh,T. J., van Dam, A. A., Beveridge, M. C. M. and Verdegem, M. C. J. 2002. The effect of periphyton and supplemental feeding on the production of the indigenous carps Tor khudree and Labeo fimbriatus. Aquaculture, 213: 207-218.

Keshavanath, P., Gangadhar, B., Ramesh, T. J., van Dam, A. A., Beveridge, M. C. M. and Verdegem, M. C. J. 2004. Effects of bamboo substrate and supplemental feeding on growth and production of hybrid red tilapia fingerlings (Oreochromis mossambicus x O. niloticus). Aquaculture, 235: 303-314.

Kuhn, D. D., Lawrence, A. L., Boardman, G. D., Patnaik, S., Marsh, L. and Flick, G. J. 2010. Evaluation of two types of bioflocs derived from biological treatment of fish effluent as feed ingredients for Pacific white shrimp, Litopenaeus vannamei. Aquaculture, 303: 28-33.

Kumar, A., Bhatnagar, A. and Garg, S. K. 2009. Growth performance, carcass composition and digestive enzyme activity of pearlspot, Etroplus suratensis (Bloch) reared in inland saline groundwater ponds providing substrate or feed. Livestock Res. Rural Dev., 21(10). http://www.lrrd.org/ lrrd21/10/kuma21180.htm (Accessed 14 March 2017)

Kunitz, M. 1947. Crystalline soybean trypsin inhibitor. II. General properties. J. Gen. Physiol., 30: 291- 310.

Le Vay, L., Rodriguez, A., Kamarudin, M. S. and Jones, D. A. 1993. Influence of live and artificial diets on tissue composition and trypsin activity in Penaeus japonicus larvae. Aquaculture, 118: 287-297.

Licia, M. P., Mario, M. R. and Guillermo, R. C. 2006. Catalytic properties of lipase extracts from Aspergillus niger. Food Tech. Biotech., 44: 247-252.

Li, P., Webb, K. A. and Gatlin, D. M. 2008. Evaluation of acidinsoluble ash as an indicator for digestibility determination with red drum, Sciaenops ocellatus and hybrid striped bass, Morone chrysops x M. saxatilis. J. World Aquac. Soc., 39(1): 120-125.

Lowry, O. H., Rosebrough, N. J., Farr, A. L. and Randall, R. J. 1951. Protein measurement with the Folin phenol reagent J. Biol. Chem., 193: 265-275.

Makarevich, T. A., Zhukova, T. V. and Ostapenya, A. P. 1993 Chemical composition and energy value of periphyton in a mesotrophic lake. Hydrobiol. J., 29: 34-38.

Maynard, L. A and Loosli, J. K. 1972. Animal nutrition, $6^{\text {th }}$ edn. McGraw-Hill, New York, 613 pp.

Miller, G. L. 1959. Use of dinitrosalicylic acid reagent for determination of reducing sugar. Annals Chem., 31: 426-428. 
Montgomery, W. L. and Gerking, S. D. 1980. Marine macro-algae as food for fishes: An evaluation of potential food quality. Env. Biol. Fishes, 5: 143-153.

Mridula, R. M., Manissary, J. K., Keshavanath, P., Shankar, K. M., Nandeesha, M. C. and Rajesh, K. M. 2003. Water quality, biofilm production and growth of fringe-lipped carp (Labeo fimbriatus) in tanks provided with two solid substrates. Aquaculture, 87: 263-267.

Mridula, R. M., Manissary, J. K., Keshavanath, P., Shankar, K. M., Nandeesha, M. C. and Rajesh, K. M. 2005. Effects of paddy straw and sugarcane bagasse on water quality, bacterial biofilm production and growth and survival of rohu, Labeo rohita (Hamilton). Aquac. Res., 36: 635-642.

Munilla-Moran, R., Stark, J. R. and Babour, A. 1990. The role of exogenous enzymes in digestion in cultured turbot larvae (Scopththalmus maximus L.). Aquaculture, 88: 337-350.

Nandeesha, M. C., Dathathri, K., Krishnamurthy, D., Varghese, T. J., Gangadhar, B. and Umesh, N. R. 1994. Effect of varied levels of protein on growth and tissue biochemistry of stunted yearlings of rohu, Labeo rohita in the absence and presence of natural food. In: De Silva, S.S. (Ed.), Fish nutrition research in Asia, Proceedings of the $5^{\text {th }}$ Asian fish nutrition workshop. AFS special publication no. 9, Asian Fisheries Society, Manila, Philippines, p. 93-99.

Nadeesha, M. C., Gangadhar, B., Varghese, T. J. and Keshavanath, P. 1998. Effect of feeding Spirulina platensis on the growth, proximate composition and organoleptic quality of common carp, Cyprinus carpio L. Aquac. Res., 29: 305-312.

Oser, B. L.1959. An integrated essential amino acid index for predicting the biological value of proteins. In: Albanese, A. A. (Ed.), Protein and amino acid nutrition, Academic Press, New York, p. 281-295.

Polunin, N. V. C. 1988. Efficient uptake of algal production by single residence herbivorous fish on the reef. J. Exp. Mar. Biol. Ecol., 123: 61-76.

Ramesh, M. R., Shankar, K. M., Mohan, C. V. and Varghese, T. J. 1999. Comparison of three plant substrates for enhancing carp growth through bacterial biofilm. Aquac. Engg., 19: 119-131.

Rao, G. R. 2011. Observations on the age and growth, maturity and fecundity of Labeo fimbriatus (Bloch) of the river Godavari. Indian J. Fish., 21: 427-444.

Sabapathy, U. and Teo, L. 1995. Some properties of the intestinal proteases of the rabbit fish, Siganus canaliculatus (Park). Fish Physiol. Biochem., 14: 215-221.

Salim, M., Aziz, I., Sultan, J. I. and Mustafa, I. 2004. Evaluation of apparent digestibility of fishmeal, sunflower meal and rice polishing for Labeo rohita. Pakistan J. Life Sci., 2: 139-44.
Saravanan, M., Alora, E. V., Ramesh, M., Malarvizhi, A. and Kavitha, C. 2011. Impact of endosulfan on certain hematological and biochemical parameters of catfish and Labeo fimbriatus: sub lethal study. Toxicol. Indus. Health, 27: $555-562$

Singh, K., Garg, S. K., Kalla, A. and Bhatnagar, A. 2003. Oilcakes as protein sources in supplementary diets for the growth of Cirrhinus mrigala (Ham.) fingerlings: laboratory and field studies. Biores. Tech., 86: 283-191.

Supamattaya, K., Kiriratnikom, S., Boonyaratpalin, M. and Borowitzka, L. 2005. Effect of a Dunaliella extract on growth performance, health condition, immune response and disease resistance in black tiger shrimp (Penaeus monodon). Aquaculture, 248: 207-216.

Swain, S., Das, S. P., Bej, D., Patel, A., Jayasankar, P., Chaudhary, B. K., Jena, J. K., Routray, P., Swain, S. K., Das, P. C., Lakra, W. S. and Das, P. 2013. Evaluation of genetic variation in Labeo fimbriatus (Bloch, 1795) populations using heterologous primers. Indian J. Fish., 60(1): 29-35.

Talwar, P. K. and Jhingran, A. G. 1991. Inland fishes of India and adjacent countries, vol. 1. Oxford and IBH Publishing Co. Pvt. Ltd., New Delhi, p. 1158.

Thompson, F. L., Abreu, P. C. and Wasielesky, W. 2002. Importance of biofilm for water quality and nourishment in intensive shrimp culture. Aquaculture, 203: 263-278.

van Dam, A. A., Beveridge, M. C. M., Azim, M. E. and Verdegem, M. C. J. 2002. The potential of fish production based on periphyton. Rev. Fish Biol. Fish., 12: 1-31.

van der Meeren, T., Mangor-Jensen, A. and Pickova, J. 2007. The effect of green water and light intensity on survival, growth and lipid composition in Atlantic cod (Gadus morhua) during intensive larval rearing. Aquaculture, 265: 206-217.

Wahab, M. A., Manan, M. A., Huda, M. A., Azim, M. E., Tollervey, A. G. and Beveridge, M. C. M. 1999. Effect of periphyton growth on bamboo substrates on growth and production of Indian major carp, rohu (Labeo rohita). Bangladesh J. Fish. Res., 3:1-10.

Xu, W. J., Pan, L. Q., Sun, X. H. and Huang, J. 2013. Effects of bioflocs on water quality, growth and digestive enzyme activities of Litopenaeus vannamei (Boone) in zero-water exchange tanks. Aquac. Res., 44: 1093-1102

Yakupitiyage, A. 1993. Constraints to the use of plant fodder as fish feed in tropical small scale tilapia culture systems: an overview. In: Kaushik, S. J. and Liquet, P. (Eds.), Fish nutrition in practice. Institut National de la Rechereche Agronomique, Les Colleuques, no. 61, Paris, p. 681-689. 